\title{
THE CORPORATE BABY IN THE BATHWATER: WHY PROPOSALS TO ABOLISH CORPORATE PERSONHOOD ARE MISGUIDED
}

\author{
David Gindis $^{*} \&$ Abraham A. Singer**
}

September 2021

\begin{abstract}
The fear that business corporations have claimed unwarranted constitutional protections which have entrenched corporate power has produced a broad social movement demanding that constitutional rights be restricted to human beings and corporate personhood be abolished. We develop a critique of these proposals organized around the three salient rationales we identify in the accompanying narrative, which we argue reflect a narrow focus on large business corporations, a misunderstanding of the legal concept of personhood, and a failure to distinguish different kinds of constitutional rights and the reasons for assigning them. Corporate personhood and corporate constitutional rights are not problematic per se once these notions are decoupled from biological, metaphysical or moral considerations. The real challenge is that we need a principled way of thinking about the priority of human over corporate persons which does not reduce the efficacy of corporate institutions or harm liberal democracies.
\end{abstract}

Keywords: corporate abolitionism; corporate personhood; corporate rights; liberal democracy

\footnotetext{
* University of Hertfordshire, Hertfordshire Business School, UK. Email: d.gindis@herts.ac.uk.

${ }^{* *}$ Loyola University Chicago, Quinlan School of Business, USA. Email: asinger2@luc.edu.

We are grateful to Bruce Barry, Francesca Gagliardi, Kent Greenfield, Geoff Hodgson, Sam Mansell, Ben Manski, Martin Petrin, Philip Pettit, Katharina Pistor, Elizabeth Pollman, Susanna Ripken, Bertrand Valiorgue, Jeroen Veldman and Adam Winkler for comments and discussions.
} 
In The Folklore of Capitalism, Thurman Arnold (1937, p. 185) wrote that "the ideal that a great corporation is endowed with the rights and prerogatives of a free individual is as essential to the acceptance of corporate rule in temporal affairs as was the ideal of the divine right of kings in an earlier day." This observation resonates with today's critics of corporate power, particularly those concerned about the extent of the constitutional protections corporations have claimed in America. There is something Arnoldian in the recent "corporate civil rights movement" (Piety, 2016) exemplified in the Supreme Court's controversial decisions in Citizens United, which held that independent political expenditures by corporations were to be protected as freedom of speech rights, ${ }^{1}$ and Hobby Lobby, which seemed to expand religious freedom protections to business corporations. ${ }^{2}$

The fear that such decisions have corroded American democracy led to the formation of a bona fide social movement demanding a constitutional amendment that restricts constitutional rights to human beings and abolishes corporate personhood. ${ }^{3}$ The narrative mobilized by what Susanna Ripken (2011) calls the "corporate abolitionist movement" is not new, but against the backdrop of the Great Recession, the perception that the Supreme Court had sided with big business hit a nerve. Support for the abolitionist proposals among local governments, state legislatures, and federal lawmakers has spread. Although the proposed amendment is unlikely to be adopted, the movement should not be taken lightly: even failed

\footnotetext{
${ }^{1}$ Citizens United v. Federal Election Commission, 558 U.S. 310 (2010).

${ }^{2}$ Burwell v. Hobby Lobby Stores Inc., 134 S. Ct. 2751 (2014).

${ }^{3}$ This debate is distinctly American. The European Court of Justice, for example, routinely talks about the fundamental rights of companies without creating any controversy (Oliver, 2015).
} 
attempts to amend the Constitution can lead to significant political change through sustained public deliberation about the institutional foundations of society (Hartley, 2017).

We share the movement's legitimate concern that excessive corporate power may have adverse effects on the functioning of modern democracies. We doubt, however, that the abolitionist proposals constitute the appropriate remedy. To explain why, we identify and reconstruct three kinds of justifications for corporate abolitionism - which we label the "Plutocracy Rationale," the "Absurdity Rationale," and the "Distinctiveness Rationale" - and proceed to evaluate each in turn, independently of given Supreme Court decisions or the campaign finance debate. ${ }^{4}$ Abolitionism, we contend, is a blunt instrument that downplays the societal and political benefits of corporate personhood, misunderstands the legal notion of personhood, and fails to distinguish different kinds of constitutional rights and the reasons for assigning them.

Given that the legal assignment of personhood and rights need not rely upon essentialist considerations about the qualities of candidate persons or rights-holders (Gindis, 2016), there is no coherent reason why we cannot recognize corporations as persons with rights while also denying them the full set of rights and privileges that we reserve for human beings. That said, the extension of rights to corporations may be taken too far. We therefore need a principled way of ensuring the priority of human persons over their corporate counterparts which does not reduce the efficacy of corporate institutions or harm liberal democracy. This question, we submit, cannot be decided categorically (Singer, 2019). The answer may instead lie in philosophical pragmatism and its commitment to institutional experimentation and social deliberation.

\footnotetext{
${ }^{4}$ We reference key Supreme Court decisions but do not discuss the specifics of the cases or the rulings. Nor do we discuss the ethical aspects of campaign finance rules (on this, see Alzola 2013; Néron, 2015).
} 


\section{END CORPORATE PERSONHOOD NOW!}

The corporate abolitionist movement, led by the umbrella organization Move to Amend, rallies around slogans such as "End Corporate Rule," "Corporations Are Not People" or "I'll believe corporations are people when Texas executes one." ${ }^{5}$ These catchphrases express a variety of powerful intuitions and normative concerns, which need to be carefully untangled. Given that they have been formulated by a broad range of activists, social critics, practicing lawyers, and academics in diverse intellectual and political contexts, we reconstruct the three most prevalent arguments against corporate personhood in general terms. By showcasing their implicit philosophical logic, we give these positions their strongest articulation and render them more scrutable to normative critique.

\section{The Abolitionist Narrative}

Like the abolitionist movement of the 19th century, corporate abolitionists frame their cause as an issue of human rights (Ripken, 2019). Their most significant slogan is "We the People, Not We the Corporations," because the goal is the adoption by Congress of the so-called "We the People Amendment" that revokes all constitutional rights granted to corporations by clarifying that these rights were meant for human beings, not the artificial persons created by law. The latest version stipulates: "The rights protected by the Constitution of the United States are the rights of natural persons only. Artificial entities, such as corporations, limited liability companies, and other entities ... shall have no rights under this Constitution ... The

\footnotetext{
${ }^{5}$ Move to Amend comprises hundreds of national and local organizations. Current members are listed at https://movetoamend.org/organizations.
} 
privileges of artificial entities shall be determined by the People, through Federal, State, or local law, and shall not be construed to be inherent or inalienable." 6

Without an amendment of this kind, abolitionists believe, corporations are in a position to abuse the Constitution, and if fact have already done so (Move to Amend, 2012). They have hijacked the First Amendment (free speech rights) to influence elections or advertise for dangerous products, appealed to the Fourth Amendment (search and seizure rights) to avoid subpoenas for unlawful trade or price fixing, and invoked the Fifth Amendment (takings and due process rights) to force compensation for future profit losses due to state regulation (Move to Amend, 2016). Corporations have also successfully resisted state regulation of their activities under the Contracts and Commerce Clauses of the Constitution (Move to Amend, 2020a). All this poses a threat to "real people," whose legitimate reaction is to put an end to the institution of corporate personhood itself (Program on Corporations, Law and Democracy, 2010).

Some abolitionists, such as activist lawyer Jeffrey Clements (2014), are relatively moderate in their proposals. They recognize that corporations must have a special legal status and a set of legal rights in order to function but want to ensure that corporations are only entitled to the rights granted by state or federal legislation (Move to Amend, 2012). They argue that corporations are creatures of state-granted privileges, not the Constitution, and point out that the legal personhood assigned by corporate law, which enables corporations to contract, sue or be sued, and so on, does not transform corporations into "persons" meriting constitutional protections. Some political theorists and legal scholars agree (Ciepley, 2013; Greenwood, 2017). From this perspective, ending the constitutional personhood of

\footnotetext{
${ }^{6}$ H. J. Res. 48, 117th Congress (2021-2022). https://www.congress.gov/bill/117th-congress/house-jointresolution/48/text. At the time of writing, the bill has 74 sponsors. 22 states and over 800 local governments have passed resolutions in support of the amendment. http://united4thepeople.org/statelocal.
} 
corporations should not impact their day-to-day operations, and of course the rights of individuals doing business through them would remain unchanged.

But other abolitionists target the corporation's status as a separate legal person more broadly. As public interest lawyer-turned sociology professor Ben Manski (2010) explains, the general problem with corporate personhood (that would exist even if corporations lacked constitutional rights) is that it comes with limited liability, which is to say that liability for the wrongs arising from corporate activities is attached to the corporation, not the individual. This allows corporate leaders to undertake harmful activities for which they would otherwise bear personal responsibility (Move to Amend, 2016). ${ }^{7}$ Furthermore, with their potentially perpetual life, corporations can amass immense power and pose grave dangers to society in the political sphere. It follows that granting constitutional personhood to corporations already using their legal personhood to aggregate economic power and evade their duties makes a bad problem worse.

Both strands of the abolitionist narrative were around well before Citizens United. In the years following law professor-turned public interest lawyer Carl Mayer's (1990) call for a constitutional amendment clarifying that the Constitution was the exclusive preserve of "real people," a number of activists, popular writers, and broadcasters came out in favor of ending the "absurdity" of corporate personhood (Grossman, 1996) on the grounds that it was intuitively wrong that courts gave corporations the attributes of human beings (Hartmann, 2002; Nace, 2003). Corporate personhood was a bad thing because, thanks to the infinite lifespans afforded by their legal personhood, corporations were effectively "superhuman," able to accumulate wealth and power forever, while we mere mortals were relegated to

\footnotetext{
${ }^{7}$ Note that this is not a critique of limited investor liability, which is not an attribute of corporate personhood and raises a different set of issues.
} 
"subhuman" status; and it was wrongly given, because the consent of We the People had not been secured (Morgan \& Edwards, 2002).

Abolitionists often trace the origins of this state of affairs to the 1886 case of Santa $\mathrm{Clara}^{8}{ }^{8}$ in which the Supreme Court assumed that corporations were persons for the purposes of the Fourteenth Amendment's equal protection clause and, by implication, ruled that due process applied to corporate property, making it more difficult to tax. This not only perverted the Fourteenth Amendment's original intent of protecting the rights of former slaves, it made a person out of a thing. ${ }^{9}$ It furthermore broke the path, without any democratic consultation, for the addition of other constitutional protections, that have since bolstered the corporate quest to escape from state interference (Cray, 2002). The fiction of corporate personhood is thus a roadblock that needs to be removed before other means of limiting corporate power and restoring democracy can be pursued (Edwards, 2002).

Calls to abolish the legal status corporations enjoy have cropped up in entirely different settings. The alter-globalization movement thus listed the need to eliminate limited liability and corporate personhood alongside limitations on capital movements and other controls on corporate activity (Cavanagh \& Mander, 2002). Related recommendations can be found in diverse corners of academic discourse. For example, renowned environmental lawyer James Speth (2008) has called for the abolition of corporate personhood in the name of the green revolution, while the idea that doing away with corporate personhood will help hold executives accountable for corporate crimes has been developed by criminologists (Tombs \& Whyte, 2015). And it has also been suggested that this will oblige those doing business to assume personal responsibility for their actions, in line with classical liberalism (Van Eeghen, 1997) and Catholic social thought (Quigley, 2004).

\footnotetext{
${ }^{8}$ Santa Clara County v. Southern Pacific R. Co., 118 U.S. 394 (1886).

${ }^{9}$ These ideas are captured in the slogan, "slavery is the legal fiction that a person is property, corporate personhood is the legal fiction that property is a person" (Morgan \& Edwards, 2002).
} 


\section{Three Rationales}

Given that it has featured in different political and intellectual contexts, the abolitionist narrative can be assessed in general terms, and not just confined to its effect on campaign finance rules or any particular Supreme Court decision. The abolitionist claim is not that corporate personhood should be limited in particular instances, or that corporations should not have certain rights, but that the whole doctrine must be thrown out. We propose a rational reconstruction of the three basic motivations that support this claim. These may partially overlap and reinforce each other, but analytically they are distinct. Certainly, while many may accept all three rationales for corporate abolitionism, the justification of the proposal does not require the acceptance of all three. It may well be that there is no one single coherent argument that all abolitionists share and endorse.

Corporate Personhood Results in Plutocracy ("The Plutocracy Rationale" hereafter). Many of the worries underlying abolitionism stem from the fear that conceiving of corporations as bearers of the rights normally reserved for human beings serves to reinforce the tremendous economic advantages they derive from their status as legal persons. By granting constitutional rights to perpetually existing entities whose legal nature already allows those running them to avoid responsibility, the worry goes, corporations are elevated to superhuman status. The Plutocracy Rationale thus contends that corporate personhood must be abolished as a prerequisite for a functioning and flourishing democracy. The alternative is to submit ourselves to a legal regime dominated by a concoction of devious economic interests, which facilitates intolerable and ever-growing inequality in social and political power.

The normative underpinning here is broadly speaking egalitarian in orientation. Corporate personhood is not ruled out as a deontological matter, or because it does not accord with some foundational moral commitment. Instead, the Plutocracy Rationale sees the 
problem of corporate personhood as resting on its social and political effects. Articulated as a counter to the raw efficiency-based or wealth-maximization logic often used to defend corporate empowerment, the Plutocracy Rationale holds that whatever the supposed economic benefits of corporate personhood are, the doctrine also grants corporations great political and economic power, leading to deeply unequal social and political relations. Corporate personhood, then, ought to be abolished because the consequences are offensive to the egalitarian commitments inherent to a democratic society.

The Very Idea of Corporate Personhood is Patently Absurd ("The Absurdity Rationale" hereafter). Probably the most intuitive justification for the abolitionist proposal, captured in slogans about the impossibly of executing corporations, is that the term "corporate personhood" defies common sense, is incoherent on its face, and must involve a category mistake. Persons are persons; corporations are corporations. This worry is buttressed by the fact that even lawyers and judges describe corporate personhood as a "legal fiction," that is, as something that exists only in contemplation of law. Since even specialists understand the notion to be contrary to reality, to base our political understandings of rights on such sophistry is to invite inanity into society. On the Absurdity Rationale, both corporate constitutional personhood and corporate legal personhood are nonsensical and must be eliminated.

The underlying objection here is that law ought to be scrutable and understandable to those subject to it. The idea is simple enough: if law establishes a state of affairs that is nonsensical and implausible it ought to be rejected; if a literal interpretation of a statute leads to absurd results then commonsense interpretations ought to be preferred. The Absurdity Rationale is thus analytically distinct from the Plutocracy Rationale: instead of directing our worries toward corporate personhood's anti-democratic consequences, it translates a concern with the law's coherence vis-à-vis basic social reasoning and concepts. But the two rationales can also work in tandem. The widespread affirmation of the absurdity that is corporate 
personhood can be cited as evidence of malign social influence. Why else would the law be so out of step with commonsense social conceptions? Why else introduce such a bizarre and counterintuitive doctrine, if not to privilege some interests over others?

Human Persons Must be Morally Distinct ("The Distinctiveness Rationale" hereafter). Abolitionism is also motivated by the idea that our political and ethical commitments require distinguishing human persons from corporate persons. By treating corporations as persons, we treat them the same as we do humans and thereby dilute the political and moral value of our own humanity. The Distinctiveness Rationale suggests that if corporate constitutional personhood remains, we will be forced to put corporations on the same constitutional footing, and accord them the same rights as other citizens: yesterday the same property and due process rights, now the same speech rights and religious freedoms, but tomorrow perhaps the same voting rights or the same rights to run for office. When we allow things to become persons, we pave the way for a process that reduces us to a kind of subhuman status. An unspoken fear here is that if law defines nonhumans as persons, perhaps it can just as easily define humans as nonpersons.

The Distinctiveness Rationale does not require endorsing the Plutocracy or Absurdity rationales. We might not think that corporate personhood will necessarily lead to plutocracy or that it is inherently absurd and still think that the assignment of rights to corporations unjustifiably places them on the same plane as us. The objection here has a Kantian flavor. Because corporations are merely means to human ends, not ends in themselves, they are not and should not be considered as equal in normative standing. When we treat corporations as persons, we undermine the special moral respect that we indisputably owe human persons. While the Distinctiveness Rationale can stand alone, it is easy to see the interplay with the Absurdity and Plutocracy rationales. If human persons did not deserve special dignity, then 
corporate personhood would not be as absurd, and we would not need to worry as much about its anti-democratic consequences.

In sum, we might say that the abolitionist position is motivated by three concerns: a concern for democratic equality; a concern for social/legal coherence; a concern for the priority of human persons in our schemes of normative justification. Abolitionists argue that the corporate person offends one or more of these values and, consequently, that some aspect of social justice or morality requires that we abandon this legal institution. In what follows, we critically evaluate and respond to each rationale in turn. We agree with abolitionists about the importance of the underlying values and understand the inclination to see corporate personhood as offensive to them. However, we do not believe that these concerns lead to the abolitionist conclusion. One need not abolish corporate personhood to criticize, rethink or reform the contemporary practice of assigning corporations rights along the lines of these values.

\section{THE PERILS OF CORPORATE ABOLITIONISM}

The Plutocracy Rationale is the justification for abolitionism with the most political cache: we should put an end to corporate personhood to prevent big business from accumulating nefarious economic and political power to the detriment of individual citizens' welfare and rights. Despite its focus on anti-democratic consequences, abolitionism motivated by this rationale typically fails to highlight the societal and political (i.e., not purely economic) benefits of corporate personhood, thereby foregoing the opportunity to weigh these against the social costs of its misuse. We offer some elements for this comparison. In criticizing the Plutocracy Rationale, we do not mean to suggest that the abolitionists' concerns for 
democratic equality are unfounded. To the contrary, we argue that a concern for democratic equality ought to make us less enthusiastic about corporate abolitionism.

\section{Corporate Abolitionism is a Blunt Instrument}

Whether corporate abolitionism targets corporate constitutional personhood, corporate legal personhood, or both, the Plutocracy Rationale invariably conjures up images of big business acting with impunity. There is a sense in which this is understandable: the potential adverse effects of business corporations seem proportional to their size. Yet this focus detracts attention from the fact that, whatever their size, business corporations are but one species of the genus that Eric Orts (2013) calls "organizational persons," which comprises a large array of business and non-business organizations that enable a modern society to function. This includes: small private companies, partnerships, cooperatives, benefit corporations, mutuals, credit unions, nonprofits, foundations, clubs, scholarly societies, trade unions, political parties, schools, universities, museums, places of worship, hospitals, municipalities, government agencies, states, and international organizations.

While they are not all incorporated in the strict meaning of the term, these organizations are artificial entities in the sense of being legally recognized and constituted as having separate legal personalities and potentially unlimited lifespans. In practice, this means that they have the capacity to hold ownership rights over assets that are distinct from the personal assets of their founders, executives or employees, and can be used as collateral to raise finance and guarantee contractual commitments over time, despite changes in their membership. The essential role of organizational law (which is broader than corporate law) is that it provides the institutional support organizations need in order to lock-in and deploy assets in a prospective manner, contract with one another, and access the courts in cases of disputes (Hansmann \& Kraakman, 2000). 
The legal personhood of business corporations is no different from that of other organizations, so it is hard to see how it might be abolished for the former but not the latter. Narrowing the target to constitutional personhood does not change this. One can deny that this is a problem in the first place. The We the People Amendment thus simply calls for all artificial entities, not just corporations, to be prevented from claiming constitutional protections. But this raises important normative questions of its own. The ability of trade unions and civic organizations to check corporate power depends on their political voice and therefore requires free speech protections (Ellerman, 2020). And the capacity of these and other organizations to protect themselves from the whims of captured bureaucrats may be seriously impaired without additional constitutional protections. As Kent Greenfield (2018) points out, all sorts of organizations would become vulnerable to government overreach, such as unreasonable searches, violations of due process or arbitrary censorship.

Abolitionists claim that such unintended consequences are largely outweighed by the highly damaging effects of corporate constitutional personhood (Move to Amend, 2020b) but offer little by way of explanation. Instead, they argue that corporate rights-holding is superfluous: protections against abuses of government power exist at common law and in state and federal law (for example the United States Code) and, at the end of the day, individual participants retain their constitutional rights, which they can vindicate in court, should the state overstep its bounds. Business corporations thus do not need protections from expropriation by government (or rights to due process or just compensation) because their shareholders already have these protections (Clements, 2014).

In assuming that the mere existence of individual protections is sufficient, this justification ignores the public goods problem facing shareholders (Olson, 1965). Even if they were to agree on the appropriate course of action, individual shareholders have little incentive to bear the costs of legal action because the benefits of successful litigation are shared. The 
larger the benefiting group, the smaller the likelihood of litigation. Government is therefore always in a relatively stronger position. This seems all the more probable in cases of artificial entities without members, such as foundations, charities, and hospitals, or artificial entities whose members hold no property interests, such as churches, universities, and political parties (Greenfield, 2018). If their constitutional personhood were abolished, all these organizations would find it harder or costlier to secure resources. Corporate abolitionism is, on the whole, a blunt instrument.

\section{Corporate Personhood as an Instrument of Collective Action}

Organizations are human groupings geared toward the collaborative pursuit of relatively specified goals that become actors in their own right thanks to their legal recognition as such (Coleman, 1990). Corporate personhood, in other words, is a generic instrument for the effective pursuit of collective action. Consider Move to Amend, which was endowed with corporate personhood following its incorporation as a nonprofit. Incorporation constituted what otherwise would have been merely a loose collection of scattered individuals into a singular vector for collective action, expanding its ability to collect and retain financial resources, and therefore greatly enhancing its lobbying capabilities. This consequence of its separate legal personhood would be for nothing if its advocacy did not benefit from free speech and other constitutional protections, including those against expropriation by powerful officials standing to lose should Move the Amend be successful in achieving its goal.

Move to Amend's reliance on the very thing it seeks to abolish shows that corporate personhood is Janus-faced: while it can serve to ennoble the position of the rich and powerful, the doctrine can also empower the marginalized. Historically, an important fight (and ultimate victory) for many voluntary associations was for the right to incorporate. Disfavored political and social groups linked with the abolition of slavery, the labor movement, religious 
minorities, and even literary clubs, were denied this right. Their weak ability to own property in perpetuity and mobilize pooled resources in the pursuit of common goals despite fluctuating memberships left them small and ephemeral (Bloch \& Lamoreaux, 2017). The growth of general incorporation laws over the course of the 19th century was a major boon for such organizations, as was their gradual assertion of due process and other constitutional protections, which allowed, for instance, their members and donors to protect their anonymity.

The long struggle to make access to corporate personhood straightforward and inclusive continued well into the 20th century, as discrimination against minorities and various dissenting groups remained pervasive. It was only in the 1950s and 1960s that the discretion of courts and legislatures to grant the corporate form to advocacy organizations was successfully challenged by the civil rights movement, which demanded, in the name of freedom of expression, freedom of association and democratic pluralism, that the nonprofit corporate form be available to all manner of interest groups as a matter of right (Silber, 2001). This resulted in the proliferation of nonprofits armed with free speech and other constitutional safeguards, many of which engaged in public interest advocacy by initiating legal actions against major business corporations or governments (Berry \& Wilcox, 2018).

Organizations are in a stronger position than individuals to push for new rights or defend, qualify, and expand existing ones, because they can overcome the public goods problem by speaking in one voice and mobilizing more resources for longer in court, where they appear as singular parties thanks to their corporate personhood (Chilton \& Versteeg, 2019). It is thus not surprising that many landmark Supreme Court cases were won by incorporated groups exercising free speech and other rights. This was how the National Association for the Advancement of Colored People confronted racial segregation ${ }^{10}$ and the

${ }^{10}$ NAACP v. Button, 371 U.S. 415 (1963). 
New York Times resisted the threat of government censorship. ${ }^{11}$ And this was how Planned Parenthood was able to defend women's choice ${ }^{12}$ and the American Civil Liberties Union succeeded in making same-sex marriage the law of the land. ${ }^{13}$ It is significant that America's most prominent defender of constitutional rights firmly opposes corporate abolitionism (American Civil Liberties Union, 2012).

Since many of the individual and collective rights we now cherish were secured in cases litigated by corporate persons, it should be clear that corporate personhood is not just a tool mobilized by big business to abuse the rights intended for individuals. While business corporations have indeed leveraged some of the rights held by individuals and have also benefited by expanding those originally secured by nonprofits (sometimes to avoid government regulation), they have also fought to uphold citizenship rights against governments, especially in developing countries (Crane et al., 2008). More importantly, they have acted as what Adam Winkler (2018) calls "constitutional first movers": early corporate rights cases (among which Santa Clara) shaped the very same understanding of equal protection and due process guarantees under the Fourteenth Amendment that later underpinned many of the Supreme Court's vital rulings, including those outlawing racial segregation in schools ${ }^{14}$ or ensuring political equality based on the one person-one vote principle. $^{15}$

The protection of individual and collective rights can sometimes require that organizations, business or otherwise, be held to account. In cases like the diesel emissions scandal, if it were not for the separate legal personhood of Volkswagen, prosecutors would

\footnotetext{
${ }^{11}$ New York Times Co. v. United States, 403 U.S. 713 (1971).

12 Planned Parenthood v. Casey, 505 U.S. 833 (1992).

${ }^{13}$ Obergefell v. Hodges, 576 U.S. 644 (2015).

${ }^{14}$ Brown v. Board of Education of Topeka, 347 U.S. 483 (1954).

${ }^{15}$ Reynolds v. Sims, 377 U.S. 533 (1964)
} 
only be able to file charges against individual managers or employees. While punishing culpable individuals is important on both legal and moral grounds, individuals will not typically have pockets deep enough to compensate for the real damages incurred by society. By contrast, the possibility to prosecute corporate persons means that something approaching real compensation might be possible (Greenfield, 2018). However, if we see corporate personhood as a mechanism for enforcing accountability, we need to recognize that corporations must also have certain protections. If they no longer had the right to due process or the right to a public trial by an impartial jury, it is hard to see what might prevent prosecutorial misconduct and other forms of injustice.

To be sure, corporate personhood can be abused and misused by the founders or executives of corporations and other organizations (Maitland, 2017). Shell entities can be set up to evade taxes and other responsibilities, and culpable individuals can go unpunished when corporate criminal liability is used as a scapegoat. Furthermore, prosecutors sometimes apply less stringent standards of justice to corporations (Garrett, 2014a). But corporate personhood is like any other legal doctrine in this respect: the potential social costs of its misuse should be weighed against the social benefits. What abolitionism motivated by the Plutocracy Rationale misses is that corporate personhood is necessary to accomplish all sorts of democratic objectives, which would be undermined if we did away with it (Piety, 2015). This does not mean that empowering the corporate person is always beneficial. But it does suggest that this balance is what the conservation should be about.

\section{UNDERSTANDING CORPORATE PERSONS}

If the Plutocracy Rationale has the most political cache, the most intuitive motivation for abolitionism is the Absurdity Rationale, which holds that the idea of corporate 
personhood ought to be rejected because fictitious corporate entities are not conscious, living agents. This objection assumes that "person" is synonymous or co-extensive with "human being." The problem with this assumption is that the law's definition of personhood need not, and does not, correspond to what the term means in ordinary language. We show that corporate personhood is more appropriately understood as a term of art denoting a point of imputation for rights and duties arising in legal relations. Since this definition does not presuppose any intrinsic biological, moral or metaphysical qualities, it is no more absurd to assign personhood to corporations than it is to human beings.

\section{The Nature of Legal Personhood}

It is difficult to understand how law works without reflecting on the idea of a person (MacCormick, 2007). This is because persons are the primitives of the legal system, the fundamental units of the legal order (Pound, 1959). In the same way that the chemist thinks of the world as ultimately made up of basic natural kinds, the legal mind thinks of the legal world as populated by persons. Law is, to a large extent, about adjusting the actions of and relations between persons, and this often involves defining the objects of their reciprocal rights and duties. Hence the distinction between "persons" and "things," or "subjects" and "objects," is essential and can be found in all systems of law and political economy, and decisions concerning who or what counts as a person from the legal point of view have profound implications.

The legal way of thinking about the persons that populate the legal realm goes back to Roman law, and to the original Latin meaning of persona, which denoted the mask work by an actor in a theatrical representation (Gindis, 2016). For Roman lawyers, persons were the actors in a legal drama, the ones that courts gave legal standing to as 
dramatis personae. In other words, they were the subjects of civil rights and duties with the ability to act as parties in the drama of litigation. The closely related concept of capacitas referred to a status conferred upon citizens for the purpose of enabling them to participate in the economic life of the polity (Deakin, 2006). In like manner, modern legal systems define capacity as the ability exercised by individuals or organizations to enter into legally-binding agreements.

Christian List and Philip Pettit (2011) usefully distinguish this "performative conception" of personhood, which emphasizes the capacity to perform effectively in the space of private and public obligations, a view held most notably by Thomas Hobbes, from the "intrinsicist conception" of personhood, which reflects in categorical terms the essence of what distinguishes persons from non-persons. The latter emphasis on what the person is, as opposed to what the person does, goes back to the idea proposed in the 6th century by Boethius that a person is an "individual substance of a rational nature." This view lies at the foundations of Western philosophy. Witness Immanuel Kant's (2002, p. 46) famous position that "beings without reason ... are called things; rational beings, by contrast, are called persons."

The influence of the intrinsicist conception on our intuitions cannot be understated. Indeed, it informs our ordinary language meaning of the term "person," as well as much of our thinking about morality. Significantly, this is the view that is entrenched in human rights discourse. As the Universal Declaration of Human Rights clarifies, all human beings are endowed with reason and conscience (Article 1), and everyone has the right to recognition, everywhere, as a person before the law (Article 6). ${ }^{16}$ In every jurisdiction, in other words, every human being - by the mere biological fact of being

\footnotetext{
${ }^{16}$ See http://www.un.org/en/universal-declaration-human-rights.
} 
born human, regardless of nationality, age or physical and mental disposition - is to be treated as a subject, as opposed to merely an object, of law.

Although this principle is a cornerstone of the Western political tradition, positive law makes a very clear distinction between the subject of human rights and what Ngaire Naffine (2003) calls the "responsible subject." ${ }^{17}$ In all jurisdictions, certain classes of human beings, including infants, minors, the mentally disabled, and those declared legally insane, are deemed to lack the capacity to make legally-binding decisions and cannot be held fully accountable for their actions or be subjected to criminal liability. The mere biological fact of being born human is insufficient: only a subset of human beings - those of a certain age and in sufficient possession of their faculties - meet the conditions that define the responsible subject, which courts typically view as the default human legal person (Blumenthal, 2007).

The difference between the subject of human rights and the responsible subject underscores the performative conception of personhood and shows that capacity is always legally determined, even when extra-legal factors, such as age or mental abilities, are used to determine its presence or absence. While infants, minors, the mentally disabled, and those declared legally insane have human rights (such as the right to life) and are the passive beneficiaries of certain legal provisions (such as the protection from bodily harm), the capacity to perform legal acts, namely the ability to play an active role in the institutional drama of life, is gained by acquiring rights, powers, and duties, which gather cumulatively (Tur, 1987) as human beings grow into the paradigmatic adults normally associated with the responsible subject.

The assignment of rights and duties, like their retraction following a conviction or some other relevant change of legal status, epitomizes the constitutive role of law

\footnotetext{
${ }^{17}$ Positive law “decomposes” legal personhood, to borrow Jon Garthoff’s (2019) expression.
} 
(Deakin et al., 2017). The persons that populate law's world are creations of law: they are abstract legal artifacts, which serve as hubs for legal relations. Legal persons are points of imputation for rights and duties arising in legal relations that are identifiable by certain bundles of rights and duties. There are no other characteristics of legal personhood. Contrary to the intrinsicist conception of personhood, which requires that we start from first principles and consider the biological, metaphysical or moral qualities of candidate persons, the conception of personhood used in law is decoupled from such considerations. This understanding of legal personhood has important implications for our evaluation of corporate abolitionism.

\section{Implications for Corporate Personhood}

The objection underlying the Absurdity Rationale has a long history. When Pope Innocent IV first described the corporation as a persona ficta in the 13th century (Canning, 1980), and Edward Coke argued that a corporation exists only in abstracto in the 17 th century, ${ }^{18}$ this was the view they subscribed to. Their refusal to hold corporations liable on precisely these grounds is the source of the maxim, attributed to Edward Thurlow, that the corporation has "no body to kick, no soul to damn." While intuitively appealing, this position is grounded in the intrinsicist conception of the person and therefore deviates from law's more abstract notion of personhood.

Nothing precludes law from constituting nonhuman legal persons. Corporate persons are a case in point. The distinction between the legal personhood of human beings and the legal personhood of corporations cannot be that the former is "natural" and therefore legitimate, while the latter is "artificial" and hence illegitimate. Legal

\footnotetext{
${ }^{18}$ Case of Sutton's Hospital, 77 Eng. Rep. 960 (1612).
} 
personhood is always artificial in the same sense that property or other established legal institutions are artificial, and it is no more a fiction to assign the capacity to perform legal acts to human beings than it is to corporations or other sorts of organizations. Human beings and corporations are persons in the same sense of being the constituent right-and-duty-bearing parties in legal relations. This is the only definition of legal personhood which includes all of law's persons, human or otherwise (Gindis, 2016).

We must resist our inclination toward ordinary language and other extra-legal ideas of the person if the discussion of corporate personhood is to advance without needless equivocations. As John Dewey (1926, p. 656) observed, “what 'person’ signifies in popular speech, or in psychology, or in philosophy or morals, [is] as irrelevant, to employ an exaggerated simile, as it would be to argue that because a wine is called 'dry,' it has the properties of dry solids; or that, because it does not have those properties, wine cannot possibly be 'dry.'” While some parts of our discourse are informed by a view of persons in the intrinsicist sense, other parts are informed by the performative conception. It is important to understand that legal personhood falls unambiguously in the latter category. To refer to "corporate personhood" is to use language technically and perhaps counterintuitively, but it is not incoherent or absurd.

That said, we must also acknowledge that the legal notion of personhood has a wider normative significance (Samuels, 1988). Our deeply-held cultural and moral convictions tend to interpret corporate personhood in terms of the intrinsicist conception, and it is the tension between the institutional logic of the legal domain and our social system of beliefs that fuels the backlash against corporate personhood (Ripken, 2019). It may seem that this tension could be defused if the legal view of personhood were to make room for biological or moral considerations. Law could, for example, reserve the term "person" for human beings and refer to corporations (and 
other organizations) as "legal entities." But we would still need a term for the class of legal actors comprising human beings and corporations (Fuller, 1967). And we would still need to address the substantive issue underpinning the debate: the real question is which rights corporations ought to have.

\section{UNDERSTANDING CORPORATE CONSTITUTIONAL RIGHTS}

Recall the worry underlying the Distinctiveness Rationale: by seeing human beings and corporations as persons in the same legal sense we are required to assign corporate persons the same constitutional status, thereby diluting our own moral and political standing. This position assumes that all legal persons have or can claim the same bundle of constitutional rights. But this is not the case: a legal regime can assign rights to corporate persons without assigning them all the rights of human persons. The challenge is not whether we can distinguish the rights of human persons from those of corporate persons; it is rather how to draw a principled distinction that preserves the priority of the former over the latter without damaging the efficacy of corporate institutions or the functioning of liberal democracies. We think the answer may lie in a pragmatist commitment to institutional experimentation and social deliberation.

\section{Corporate Constitutional Rights: Derivative or Sui Generis?}

It is important to unpack the concept of legal rights. As Wesley Newcomb Hohfeld (1919) famously noted, the term is used indiscriminately to denote four different kinds of legal advantage that really ought to be distinguished A legal right can refer to: (a) a legal power, namely the ability to bring about some change in one's or others' legal 
situation by performing some operative action; (b) a legal privilege or liberty, namely the absence of any contrary legal duty; (c) a legal claim, which is the correlative of a corresponding legal duty of some other party; or (d) a legal immunity from some legal consequence, which is the correlative of the absence of some other party's legal power to effect that consequence.

Rights can furthermore be classified as "active," when they require the rightholder's actions, or "passive," when they involve recognition or action by others (Rainbolt, 2006). The distinction applies to constitutional rights, which are a species of legal rights, albeit a fundamental one (Wellman, 2016). Liberty-rights (to speak or assemble) and power-rights (to vote) are active; claim-rights (to just compensation) and immunity-rights (against double jeopardy) are passive. The scope and exercise of rights is not absolute. For example, free speech is limited because it does not extend to libel or incitement to violence, while voting rights do not belong to citizens of other nationstates or corporate persons. That constitutional rights do not automatically or categorically extend to corporate persons raises, but does not answer, a series of complex questions.

Professing an unwavering belief that constitutional rights are inalienable and belong to human beings alone does not really explain why corporate persons ought to be unconditionally excluded from being bearers or claimants of constitutional rights. The Constitution recognizes some inalienable rights which apply only to human persons based on certain intrinsic biological or moral properties they possess, but it also codifies the civil rights of citizens, which are a far murkier category. Contrary to the freedom of thought (or the right to life, liberty, and the pursuit of happiness famously mentioned in the Declaration of Independence), the assignment of civil rights is performative: it expresses the status conferred on some in a specific legal and political regime and 
cannot be decided based solely on the presence or absence of human qualities. Their purposes must be considered (Garrett, 2014b).

To this end, the Supreme Court deploys, or ought to deploy, a "functional purpose and fit analysis" which asks what the objective of the right is and whether extending it to the claimant will fulfil that objective (Pollman, 2011; Robinson, 2016). Many constitutional rights are meant to limit governmental overreach, so what matters is the constraint on government, not the identity of the right-holder (Greenfield, 2018). The immunity-right against unreasonable search and seizure and the claim-right to just compensation in the event that property is taken for public use have been assigned to corporate persons, not because of any intrinsic properties they may share with human persons, but because doing so serves the purpose of limiting arbitrary uses of government power. By contrast, the power-right to vote has not been extended to corporate persons because this would not serve its purpose of allowing what Amy Sepinwall (2012) calls "normative citizens" to use the ballot to take part in the joint project of the nation-state.

In cases where it has extended constitutional protections to corporate persons, it seems that the Court has generally believed that this was a necessary or convenient way to protect or enhance the rights of human persons. As Margaret Blair and Elizabeth Pollman (2015) argue, the Court has long viewed corporations as aggregates of individuals, and corporate constitutional rights as "derivative" of the "original" rights of those individuals. Thus, when it extends the liberty-right to free speech to, say, a news corporation, it understands the corporate liberty-right to free speech to be derivative of the active liberty-right to free speech of the editors and reporters involved. But it also instrumentally protects the rights of third parties, namely the readers' or listeners' passive claim-right of non-interference against the government (Kendrick, 2017). This 
explanation of the Court's thinking does not imply that its rulings never end up harming people any more than it suggests that they are always morally just.

Even the legal coherence of some of the Court's rulings can be called into question. The idea that granting corporate persons constitutional rights is a way of giving effect to their members' original rights conflicts with the basic legal principle that the corporation is a separate legal person with its own rights and duties. Legally, the corporate person has a sui generis capacity for property, contract, and litigation, such that when it enters a legally-binding agreement to acquire assets, for example, it is not exercising its members' rights, but exercising its own rights, on its own behalf. The same ought to hold for corporate constitutional rights. Historically, it seems that fewer rights were granted to corporations when the Court upheld this principle, and more rights were granted when it was disregarded (Winkler, 2018). ${ }^{19}$ Of course, whatever the justification for granting corporations rights and whatever their provenance, once assigned they are not reducible to the rights of individuals; they are, properly speaking, the corporate person's

It might be objected that corporate persons cannot really hold rights because to hold a right is to have the autonomous ability to decide whether or not to enforce it (Steiner, 1998). On this "will theory of rights," which relies on the intrinsicist conception of personhood, only an agent can be a real legal right-holder (Wellman, 1995), and only active rights count. This implies that infants are not real right-holders, and that a corporation can only be a real right-holder if it has volition. Similar questions underlie contemporary discussions of corporate moral agency and corporate moral personhood (Schragger \& Schwartzman, 2016) ${ }^{20}$ This is grist for the abolitionist's mill:

\footnotetext{
${ }^{19}$ Paradoxically, corporate empowerment has thus been curbed by more corporate personhood, not less (Greenfield, 2018).

${ }^{20}$ It is impossible to do justice to this rich literature associated with Thomas Donaldson (1982) and
} 
to view corporations as the types of things capable of bearing rights seems to imply that we see them as possessing wills or other things that are uniquely human.

Yet rights need not imply such thick metaphysical commitments about volition. Relevant normative, legal, and political arguments can and ought to be made with as minimal metaphysical commitments as possible, given that such commitments are neither necessary nor sufficient for establishing the desirability of corporate personhood (Singer, 2018). It may be legitimate to recognize corporate rights even if corporations are not moral persons, or to deny corporations certain rights, even if it turned out that they were moral persons (Sepinwall, 2015). We may also hold corporations legally responsible even if they are not proper moral agents. There can be valid public policy reasons for doing any of these things. The important institutional fact is that corporate persons are legal agents, and the important question is which rights these legal agents ought to have. The will theory of rights is of little help here.

When rights are instead construed as involving the normative protection of some aspect of the right-holder's interests (Kramer, 2001), what matters is that these are protected, in the sense that duties toward the right-holder are imposed on others, regardless of the right-holder's volition. This "interest theory of rights" accommodates active and passive rights, and extends to infants and other non-autonomous human persons while applying to non-autonomous nonhuman persons such as corporations (Kurki, 2019). ${ }^{21}$ Organizations set up to pursue the interests of their members despite membership changes, or fulfil the purposes of their founders beyond their lifetimes, have an interest in cohesion and persistence, which we ought to recognize, taking into account the interests of third parties or the community (Pettit, 2015). This view sits

others here.

${ }^{21}$ A deeper discussion of the relative merits of will and interest theories of rights is beyond the scope of this paper. 
comfortably with the idea that corporate persons might be granted rights in order that they can perform effectively in the space of private and public obligations.

\section{The Priority of Human Persons}

Corporate persons can be legitimate holders of constitutional rights and nothing in the doctrine of corporate personhood requires that corporations be granted the same complement of rights as human persons. But the Distinctiveness Rationale cannot be rebutted by merely distinguishing the rights granted to corporate persons from those held by human persons. The trouble is that once certain rights are assigned to corporate persons, they become not just sui generis but also very difficult to weaken or reverse, making them, as abolitionists argue, potentially a threat to ordinary citizens. Yet while corporations can leverage constitutional rights to amass economic and political power, the idea that abolishing corporate personhood will help restore democracy - recall the primary motivation of the Plutocracy Rationale - is a nonstarter, as this will also eliminate vital resources for collective action and democratic empowerment.

Consequently, if we value democratic equality and want to preserve a vibrant and open civil society, we need a principled way of ensuring the priority of human over corporate persons which not only preserves the efficacy of corporate institutions but also prevents law from defining humans as nonpersons. One prominent strategy involves what may be called the "deontic priority" argument. Derived from the Kantian accent on the uniquely human attribute of autonomy and rationality (or at least the disposition for autonomy and rationality), this argument suggests that because corporate persons are non-autonomous means to human ends, their rights do not deserve the same respect (Dan-Cohen, 1986). Whatever its merits, this approach is very closely connected with 
the intrinsicist notion of personhood and the will theory of rights, which we believe are not necessary to establish the priority of human persons.

A somewhat less categorical argument stems from the political conception of citizens as "self-authenticating sources" of claims on the institutions of society (Rawls, 1993). This Neo-Kantian approach translates the idea of human beings as ends in themselves into the idea of human beings as moral persons that are owed a justification for the conditions and treatment imposed onto them by others, and especially by social, legal, and political institutions (Forst, 2014). Given that corporations are such institutions, they are not the sorts of entities to which justifications are owed. It follows that corporate persons should have those rights that can be justified by and to human persons, but that they do not require (and should not be granted) those rights owed to beings that have a right to justification. The content and nature, but also the extent and limitation, of corporate rights is determined on behalf of, not in spite of, a foundational moral regard that we reserve for human beings as justificatory agents.

But the claim that corporations ought to have those rights that can be justified to human persons, and not those rights that cannot be justified to human persons, seems mealy-mouthed. Moreover, its premise, that we do not have to justify ourselves to corporate persons, is implausible, given that cases where corporate persons challenge the way they are treated by prosecutors or tax authorities are cases where they seek justification. Courts do not dismiss these challenges on the basis that the state need not justify itself to corporations. To help us secure at a principled level the distinctiveness and priority of human persons over their corporate counterparts in our scheme of rights and liberties, an alternative route is needed. Philosophical pragmatism, we submit, can offer a fruitful avenue in this respect. 
Pragmatism is a philosophical tradition that, though diverse and containing various interpretations, is fundamentally committed to the idea that our knowledge of the world cannot be separated from our engagement with it. Concepts and normative categories are seen as forms of action that we engage because of their supposed consequences. For pragmatists, the test of an idea's validity is fundamentally linked with its usefulness; it is not evaluated in terms of its fit with first principles. Because of its practical orientation and its anti-foundationalism, scholars in business ethics and management studies are increasingly turning to pragmatism as a touchstone for analyses that are capable of social critique yet resistant to the sorts of commitments that are difficult to maintain in a diverse and complex world (Farjoun et al., 2015; Visser, 2019).

Pragmatism offers us a chance to set aside grand moral theories about rights in order to focus more directly on the consequences of different sorts of social action (Pouryousefi \& Freeman, forthcoming). Its methodological resistance to deontological positions, which can lead to the intrinsicist conception of personhood and the will theory of rights, makes it uniquely suited to the task of addressing the question of corporate personhood (Singer, 2019). And its normative commitment to democratic equality as a basis for criticizing social and economic institutions also allows us to engage with the worries underlying the Plutocracy and Distinctiveness rationales.

These attractive features of pragmatism flow from its core tenet of fallibilism: because we know we are fallible, we cannot pre-commit ourselves to any particular core doctrine with certainty (Dewey, 1920). We must instead always subject our beliefs and convictions to an ongoing process of falsification through exposure to new ideas, new experiences, and open reason-giving. The firm commitment to maintaining the channels of inquiry and experimentation necessary for establishing which actions and conceptions will lead to which consequences means that nothing is inherently off the table, as long 
as we do not short-circuit our ability to reflect upon and revise our considered collective moral and political judgments (Bohman, 1999). We thus have a principled reason for both recognizing corporate persons - corporate voice adds a valuable point of view to the process of social deliberation - and asserting that whatever rights we assign to them are reconfigurable or even reversible.

The question of which rights ought to be assigned to corporate persons is something to be critically and experimentally determined (Dewey, 1927). It must always remain subject to reflection, justification, and revision. To claim either that personhood must be reserved for humans, or that the common legal designator of personhood requires an equal bundle of rights, is to let social institutions and conventions dictate the terms of social analysis, when it ought to be the other way around. Of course, one might worry that this sort of reflexive stance could justify restricting rights of human persons as well. Would we not have to subject basic human rights to the same sort of potential revision? How can we preserve the distinctiveness and priority of human persons when disavowing the very idea of categorical prioritization, potentially subjecting everything to radical reflection and critique?

From a pragmatist perspective, the contingency of corporate rights and the priority of human persons can be asserted and defended by reference to the conditions necessary for legitimate, competent, and effective inquiry. Effectively answering the question of which rights we should grant to corporate persons presupposes that we have a system of collective inquiry capable of identifying the individual and collective interests that merit protection and assessing the consequences of the legal and political decisions underlying alternative assignments of rights. In modern societies, a crucial part of this system of inquiry is the protection of political and social rights associated with democracy, which we grant to human persons to guarantee their inclusive and equal participation in the 
social processes of experimentation, assessment, and reflection. This is why pragmatists are committed to democratic equality (Jackson 2018).

On the "democratic priority" view defended here, human persons have a claim to equal treatment not because of their intrinsic capacities, but because to do otherwise undermines our epistemic confidence in, and thus the legitimacy of, our institutionalized forms of collective inquiry - the processes by which things come to be known or decided upon at a societal level (Knight \& Johnson, 2011). The priority of human persons, and the principled reason to promote and vigorously guard their equal “empowered inclusion" (Warren, 2017), is due to democracy's particular socialepistemic competence, not its derivation from a set of moralized human essences. The democratic priority argument thus offers a fairly parsimonious explanation of why corporate persons can have rights but are not entitled to the same presumption of equality as human persons are. It also helps explain why we should want to attenuate or restrict corporate persons from having certain rights as a matter of principle.

When deciding, for instance, whether corporate persons should have the same rights as human persons to support favored political candidates, we should ask whether this would corrupt or stunt the democratic background necessary for collective inquiry. Whenever it contributes to an unequal ability of human persons to participate in democratic procedures and deliberation, we undermine democracy's attractive experimental and reflexive qualities (Singer, 2019). Restricting the political and civic freedoms of corporate persons thus will often be warranted, despite the fact that they are generally capable of bearing rights. Given that the basis for such rights is in their contribution for epistemic and social inquiry, the political speech rights of corporate persons, notably those designed to accumulate stores of wealth, ought not receive the 
same level of protection as human persons' rights, lest we undercut our ability to reflect upon and revise such an institutional arrangement.

\section{CONCLUSION}

The view that the assignment of constitutional rights to corporations is a judicial travesty is shared by a broad range of activists, social critics, practicing lawyers, legislators, and academics, many of whom back proposals to restrict constitutional rights to human beings and abolish corporate personhood. Corporate abolitionism stems from three genuine concerns, namely that corporate personhood enables a plutocratic regime, trades in absurd legal designations, and intolerably places corporate and human persons on equal normative footing. In response, we have shown that corporate abolitionism is a blunt instrument that unjustifiably removes an important tool for collective action and democratic empowerment; that corporate personhood is a legal term of art and a rather straightforward one at that; and finally that there is nothing in the doctrine of corporate personhood that requires corporate persons be granted the same complement of rights as human persons.

Although corporate abolitionism is ill-advised and the abolitionist amendment will likely never be adopted, the abolitionist movement has done much both to spread awareness of the perils of corporate empowerment and to mobilize political energies around this important issue. These efforts may not be in vain: sustained democratic deliberation about the institutional infrastructure of society, as Manski (2017) notes, can be a powerful vector for effecting political change. For example, although the women's movement fight for the Equal Rights Amendment to prohibit sex discrimination was unsuccessful in the 1970s, the law today operates as if the amendment had been adopted (Hartley, 2017). This outcome was not produced by a single-minded focus on a 
constitutional amendment but rather by the direction of collective energies and resources toward many smaller policy battles.

There is a lesson for the abolitionist movement here. For instance, concerns over corporate empowerment may be better served by trying to compel the Supreme Court to recognize that corporate speech is substantively different from other kinds of speech. The Court has reversed over 300 of its own decisions, including in several of the cases mentioned in this paper (Congressional Research Service, 2016). In about half of these cases, rulings were overturned within the first 20 years; two thirds were overturned within 30 years. Citizens United thus represents the beginning, not the end, of the debate about the scope of First Amendment rights for corporate persons (Orts, 2013). To gain more traction in this debate, critics of corporate constitutional rights need to formulate stronger arguments in support of their position.

We believe that such arguments are bound to fail if they are expressed in categorical terms, treat corporate personhood as nothing but an aberration, and bundle all kinds of constitutional rights together. Given that the justifications for different corporate rights are as varied as the organizations that are affected, any serious critique requires care and nuance. We have suggested some ways of thinking about these issues, centering on the pragmatist commitment to open and reflexive social inquiry, and the related normative commitment to democratic equality. Instead of attempting to abolish corporate personhood simpliciter or eliminating all corporate rights, such commitments favor political debates over which rights corporations should not be granted and how to reconfigure the rights they do have in order to protect democratic equality. This will help clarify the underlying social objectives that we want corporations to actually serve. 


\section{REFERENCES}

Alzola, M. (2013). Corporate Dystopia: The Ethics of Corporate Political Spending. Business and Society, 52(3), 388-426.

American Civil Liberties Union (2012, July 24). Written testimony. In Taking Back Our Democracy: Responding to Citizens United and the Rise of Super PACS:

Hearings before the Subcommittee on Constitution, Civil Rights and Human Rights of the Senate Committee on the Judiciary, US Senate, 112th Congress, 1st Session (pp. 111-119). Washington, DC: U.S. Government Printing Office.

Arnold, A. (1937). The Folklore of Capitalism. New Haven, CT: Yale University Press.

Berry, J. M., \& Wilcox, C. (2018). Interest Group Society. 6th edn. London: Routledge.

Blair, M. M., \& Pollman, E. (2015). The Derivative Nature of Corporate Constitutional Rights. William \& Mary Law Review, 56(5), 1673-1734.

Bloch, R. H., \& Lamoreaux, N. R. (2017). Voluntary Associations, Corporate Rights, and the State: Legal Constraints on the Development of American Civil Society, 17501900. In N. R. Lamoreaux \& J. J. Wallis (Eds.), Organizations, Civil Society, and the Roots of Development (pp. 231-290). Chicago, IL: University of Chicago Press.

Blumenthal, S. L. (2007). The Default Legal Person. UCLA Law Review, 54(5), 1135 1265.

Bohman, J. (1999). Democracy as Inquiry, Inquiry as Democratic: Pragmatism, Social Science and the Cognitive Division of Labor. American Journal of Political Science, 43(2), 590-607.

Canning, J. P. (1980). The Corporation in the Political Thought of the Italian Jurists of the Thirteenth and Fourteenth Centuries. History of Political Thought, 1(1): 9-32. 
Cavanagh, J., \& Mander, J. (Eds.) (2002). Alternatives to Globalization: A Better World in Possible. San Francesco, CA: Berrett-Koehler.

Chilton, A., \& Versteeg, M. (2020). How Constitutional Rights Matter. New York: Oxford University Press.

Ciepley, D. (2013). Neither Persons nor Associations: Against Constitutional Rights for Corporations. Journal of Law and Courts, 1(2), 221-245.

Clements, J. D. (2014). Corporations Are Not People: Why They Have More Rights Than You Do, and What You Can Do About It (2nd ed). San Francisco, CA: BerretKoehler.

Coleman, J. S. (1990). Foundations of Social Theory. Cambridge, MA: Harvard University Press.

Congressional Research Service (2016). Supreme Court Decisions Overruled by Subsequent Decision. In The Constitution of the United States of America: Analysis and Interpretation, S. Doc. 112-9, US Senate, 112th Congress, 2nd Session (pp. 2603-2615). Washington, DC: U.S. Government Printing Office.

Crane, A., Matten, D., \& Moon, J. (2008). Corporations and Citizenship. Cambridge, UK: Cambridge University Press.

Cray, C. (2002). Chartering a New Course: Revoking Corporations' Right to Exist. Multinational Monitor, 23(10-11), 8-11.

Dan-Cohen, M. (1986). Rights, Persons, and Organizations: A Legal Theory for Bureaucratic Society. Berkeley, CA: University of California Press.

Deakin, S. (2006). Capacitas: Contract Law and the Institutional Foundations of a Market Economy. European Review of Contract Law, 2(3), 317-341. 
Deakin, S., Gindis, D., Hodgson, G. M., Huang, K., \& Pistor, K. (2017). Legal Institutionalism: Capitalism and the Constitutive Role of Law. Journal of Comparative Economics, 45(1), 188-200.

Dewey, J. (1920). Reconstruction in Philosophy. New York: Henry Holt \& Co.

Dewey, J. (1926). The Historic Background of Corporate Legal Personality. Yale Law Journal, 35(6), 655-673.

Dewey, J. (1927). The Public and Its Problems: An Essay in Political Inquiry. New York: Henry Hold \& Co.

Donaldson, T. (1982). Corporations and Morality. Englewood Cliffs, NJ: Prentice-Hall.

Edwards, J. (2002). Challenging Corporate Personhood: An Interview with Jan Edwards. Multinational Monitor, 23(10-11), 30-32.

Ellerman, D. (2020). Fallacies of Corporate Analysis. Challenge. 63(3), 133-155.

Farjoun, M., Ansell, C., \& Boin, A. (2015). Pragmatism in Organization Studies: Meeting the Challenges of a Dynamic and Complex World. Organization Science, 26(6), 1787-1804.

Forst, R. (2014). The Right to Justification: Elements of a Constructivist Theory of Justice. (J. Flynn, Trans.). New York: Columbia University Press.

Fuller, L. L. (1967). Legal Fictions. Stanford, CA: Stanford University Press.

Garrett, B. L. (2014a). Too Big to Jail: How Prosecutors Compromise with Corporations. Cambridge, MA: Harvard University Press.

Garrett, B. L. (2014b). The Constitutional Standing of Corporations. University of Pennsylvania Law Review, 163(1), 95-164. 
Garthoff, J. (2019). Decomposing Legal Personhood. Journal of Business Ethics 154(4), 967-974.

Gindis, D. (2016). Legal Personhood and the Firm: Avoiding Anthropomorphism and Equivocation. Journal of Institutional Economics, 12(3), 499-513.

Greenfield, K. (2018). Corporations Are People Too (And They Should Act Like It). New Haven, CT: Yale University Press.

Greenwood, D. J. H. (2017). Neofeudalism: The Surprising Foundations of Corporate Constitutional Rights. University of Illinois Law Review, 2017(1), 163-222.

Grossman, R I. (1996). Revoking the Corporation. Journal of Environmental Law and Litigation, 11(1), 141-152.

Hansmann, H., \& Kraakman, R. R. (2000). The Essential Role of Organizational Law. Yale Law Journal, 110(3), 387-440.

Hartley, R. C. (2017). How Failed Attempts to Amend the Constitution Mobilize Political Change. Nashville, TN: Vanderbilt University Press.

Hartmann, T. (2002). Unequal Protection: The Rise of Corporate Dominance and the Theft of Human Rights. Emmaus, PA: Rodale.

Hohfeld, W. N. (1919). Fundamental Legal Conceptions as Applied in Judicial Reasoning, and Other Legal Essays. New Haven, CT: Yale University Press.

Jackson, J. (2018). Equality Beyond Debate: John Dewey’s Pragmatic Idea of Democracy. Cambridge, UK: Cambridge University Press.

Kant, I. (2002). Groundwork for the Metaphysics of Morals. (A. W. Wood, Trans.). New Haven, CT: Yale University Press. 
Kendrick, L. (2017). Are Speech Rights for Speakers? Virginia Law Review, 103(8), 1767-1809.

Knight, J., \& Johnson, J. (2011). The Priority of Democracy: Political Consequences of Pragmatism. Princeton, NJ: Princeton University Press.

Kramer, M. H. (2001). Getting Rights Right. In M. J. Kramer (Ed.), Rights, Wrongs and Responsibilities (pp. 28-95). Basingstoke, UK: Palgrave Macmillan.

Kurki, V. A. J. (2019). A Theory of Legal Personhood. New York: Oxford University Press.

List, C., \& Pettit, P. (2011). Group Agency: The Possibility, Design and Status of Corporate Actors. New York: Oxford University Press.

MacCormick, N. D. (2007). Institutions of Law: An Essay in Legal Theory. Oxford, UK: Oxford University Press.

Maitland, I. (2017). How Insiders Abuse the Idea of Corporate Personality. In E. W. Orts, \& N.C. Smith (Eds.), The Moral Responsibility of Firms (pp. 106-122). New York: Oxford University Press.

Manski, B. (2010, January 10). The Essence of the Corporation. Democracy Square. Retrieved from http://ds.liberalart.space/publications-talks/essence-corporation.

Manski, B. (2017). Beginning the World Again: Social Movements and the Challenge of Constitutional Change. In K. E. Iyall Smith, L. E. Esparza, \& J. R. Blau (Eds.), Human Rights Of, By, and For the People: How to Critique and Change the US Constitution (pp. 31-40). New York: Routledge.

Mayer, C. J. (1990). Personalizing the Impersonal: Corporations and the Bill of Rights. Hastings Law Journal, 41(3), 577-667. 
Morgan, M., \&, Edwards, J. (2002). Abolish Corporate Personhood. Guild Practitioner, 59(4), 209-215.

Move to Amend (2012, July 18). Written testimony. In Taking Back Our Democracy: Responding to Citizens United and the Rise of Super PACS: Hearings before the Subcommittee on Constitution, Civil Rights and Human Rights of the Senate Committee on the Judiciary, US Senate, 112th Congress, 1st Session (pp. 202211). Washington, DC: U.S. Government Printing Office.

Move to Amend (2016, April). The Path to the 28th Amendment: Strategic Plan to Pass the "We the People Amendment" to the United States Constitution [Online]. Retrieved from https://www.movetoamend.org/plan.

Move to Amend (2020a, January). Corporate Rule Transcends Citizens United [Online]. Retrieved from https://www.movetoamend.org/corporate-constitutional-rights.

Move to Amend (2020b, March). Myths of Harmful "Unintended Consequences" of Abolishing Corporate Personhood [Online]. Retrieved from https://www.movetoamend.org/corporate-constitutional-rights.

Nace, T. (2003). Gangs of America: The Rise of Corporate Power and the Disabling of Democracy. San Francisco, CA: Berret-Koehler.

Naffine, N. (2003). Who are Law's Persons? From Cheshire Cats to Responsible Subject. Modern Law Review, 66(3), 346-367.

Néron, P.-Y. (2015). Rethinking the Ethics of Corporate Political Activities in a PostCitizens United Era: Political Equality, Corporate Citizenship and Market Failures. Journal of Business Ethics, 136(4), 715-728.

Oliver, P. (2015). Companies and Their Fundamental Rights: A Comparative Perspective. International and Comparative Law Quarterly, 64(3), 661-696. 
Olson, M. (1965). The Logic of Collective Action: Public Goods and the Theory of Groups. Cambridge, MA: Harvard University Press.

Orts, E. (2013). Business Persons: A Legal Theory of the Firm. New York: Oxford University Press.

Pettit, P. (2015). Two Fallacies about Corporations. In S. Rangan (Ed.), Performance and Progress: Essays on Capitalism, Business, and Society (pp. 379-394). New York: Oxford University Press.

Piety, T. S. (2015). Why Personhood Matters. Constitutional Commentary, 30(2), 361390.

Piety, T. R. (2016). The First Amendment and the Corporate Civil Rights Movement. Journal of Business and Technology Law, 11(1), 1-24.

Pollman, E. (2011). Reconceiving Corporate Personhood. Utah Law Review, 2011(4), $1629-1675$.

Pound, R. (1959). Jurisprudence (Vol. 4). St. Paul, MN: West Publishing.

Pouryousefi, S \& Freeman R.E. (forthcoming). The Promise of Pragmatism: Richard Rorty and Business Ethics. Business Ethics Quarterly.

Program on Corporations, Law and Democracy (2010, November). Why Abolish All Corporate Constitutional Rights. By What Authority. Retrieved from https://www.poclad.org/BWA/files/2010-11/BWANov2010.pdf.

Quigley, W. (2004). Catholic Social Thought and the Amorality of Large Corporations: Time to Abolish Corporate Personhood. Loyola Journal of Public Interest Law, $5(1), 109-134$.

Rainbolt, G. W. (2006). The Concept of Rights. Dordrecht, The Netherlands: Springer. 
Rawls, J. (1993). Political Liberalism. New York: Columbia University Press.

Ripken, S. K. (2011). Corporate First Amendment Rights after Citizens United: An Analysis of the Popular Movement to End the Constitutional Personhood of Corporations. University of Pennsylvania Journal of Business Law, 14(1), 209259.

Ripken, S. K. (2019). Corporate Personhood. Cambridge, UK: Cambridge University Press.

Robinson, Z. (2016). Constitutional Personhood. George Washington Law Review, 84(3), 605-667.

Samuels, W. J. (1988). The Idea of the Corporation as a Person: On the Normative Significance of Judicial Language. In W. J. Samuels, \& A. S. Miller (Eds.), Corporations and Society: Power and Responsibility (pp. 113-129). New York: Greenwood Press.

Schragger, R., \& Schwartzman, M. (2016). Some Realism about Corporate Rights. In M. Schwartzman, C. Flanders, \& Z. Robinson (Eds.), The Rise of Corporate Religious Liberty (pp. 345-371). New York: Oxford University Press.

Sepinwall, A. (2012). Citizens United and the Ineluctable Question of Corporate Citizenship. Connecticut Law Review, 44(3), 575-615.

Sepinwall, A. (2015). Denying Corporate Rights and Punishing Corporate Wrongs. Business Ethics Quarterly, 25(4), 517-534.

Silber, N. I. (2001). A Corporate Form of Freedom: The Emergence of the Modern Nonprofit Sector. Boulder, CO: Westview. 
Singer, A. A. (2018). The Form of the Firm: A Normative Political Theory of the Corporation. New York: Oxford University Press.

Singer, A. A. (2019). Toward a Pragmatist Approach to Corporate Personality and Responsibility: Why Democracy Matters. Georgetown Journal of Law and Public Policy, 17 (Special Issue), 795-810.

Speth, J. G. (2008). The Bridge at the Edge of the World: Capitalism, the Environment and the Crossing from Crisis to Sustainability. New Haven, CT: Yale University Press.

Steiner, H. (1998). Working Rights. In M. H. Kramer, N. E. Simmonds, \& H. Steiner (Ed.) A Debate Over Rights: Philosophical Enquiries (pp. 233-301). Oxford, UK: Oxford University Press.

Tombs, S., \& Whyte, D. (2015). The Corporate Criminal: Why Corporations Must Be Abolished. Oxon, UK: Routledge.

Tur, R. (1987). The "Person" in Law. In A. R. Peacocke, \& G. Gillett (Eds.), Persons and Personality: A Contemporary Enquiry (pp. 116-129). Oxford, UK: Blackwell.

Van Eeghen, P.-H. (1997). The Capitalist Case Against the Corporation. Review of Social Economy, 55(1), 85-113.

Visser, M. (2019). Pragmatism, Critical Theory and Business Ethics: Converging Lines. Journal of Business Ethics, 156(1), 45-57.

Warren, M. (2017). A Problem-Based Approach to Democratic Theory. American Political Science Review, 111(1), 39-53.

Wellman, C. (1995). Real Rights. New York: Oxford University Press. 
Wellman, C. (2016). Constitutional Rights - What They Are and What They Ought To Be. Cham, Switzerland: Springer.

Winkler, A. (2018). We the Corporations: How American Businesses Won Their Civil Rights. New York: W.W. Norton. 